Acta Horticulturae et Regiotecturae 1

Nitra, Slovaca Universitas Agriculturae Nitriae, 2016, pp. 4-7

\title{
EXAMINATION OF BASIC VARIETY CHARACTERISTICS OF SWEET CORN IN CONDITIONS OF THE SOUTHERN SLOVAKIA
}

\author{
Silvia BARÁTOVÁ*, Miroslav ŠLOSÁR, Alena ANDREJIOVÁ \\ Slovak University of Agriculture in Nitra, Slovak Republic
}

\begin{abstract}
The production of sweet corn has been increased recently. It is a very delicious vegetable species with wide variety assortment. Nowadays, new varieties which come to markets are characterized by improved properties, higher sugar content and their stability in storage. Thus, it is necessary to know basic variety parameters for better orientation in wide corn assortment. According to earliness, sweet corn varieties were classified to following groups: very early or early (RISING SUN F1; 874 F1; SF 1073 F1; SF 583 F1); middle-late (SF 681 F1; 1027 F1; ASTRONAUT F1); late (GALAXY F1; SPACE SHIP F1) and very late (MATADOR F1). The day number from tassel anthesis to harvest is an important parameter of sweet corn for potential grower and its lowest value was found at variety RISING SUN F1. On the basis of gained results, we classified all evaluated varieties to the group of super-sweet corn (sh-2) with slow decline of sugar content and storage possibility in cold conditions from 4 to 7 days after harvest. The sugar content of sweet corn is a parameter having important role for purchase by consumers. The variety had statistically significant impact to the sugar content and its highest value was determined at variety $874 \mathrm{~F} 1$.
\end{abstract}

Keywords: sweet corn, variety characteristics, sugar content, storage

The sweet corn (Zea mays L. convar. saccharata Koern.) belongs to the Poaceae family and Zea L. genus. It is a oneyear, monoecious, mostly strange-pollinated plant. In the world, it is called as sweet corn, zuckermais or kukuruza sacharnaja (Abuzar et al., 2011). In the 1980s, sweet corn belonged to the most widely cultivated vegetable species, grown almost in all states of the USA (Shafi et al., 2012). Nowadays, its biggest producers are the USA, China, Brazil, the European Union countries and Mexico. More than $40 \%$ of world-wide corn yield is grown in the USA, which is the biggest world exporter of this important crop (Eskandarnejad et al., 2013). World-widely, approximately $21 \%$ of produced corn grain is asserted as food. The production of sweet corn has been increased recently and its importance as grown vegetable species has been increasing world-widely (Moradi Dezfuli et al., 2008). According to actual data of the Research Institute of Agricultural and Food Economics, the total sweet corn in Slovakia ranged from $8997 \mathrm{t}$ to $13759 \mathrm{t}$ in period 2009-2011 (Meravá, 2012).

The edible part of this delicious vegetable species is delicious spadix of milk or waxy-milk grain maturity. In the stage of milk maturity, the sweet corn grain contains high ratio of sugars and it is most suitable for cooking processing. It is consumed after boiling, steaming, grilling or conservation (Abuzar et al., 2011). The energetic value of sweet corn is high up to $4440 \mathrm{~kJ} \mathrm{~kg}^{-1}$. Its grains contain about $35 \mathrm{~g}$ proteins $\mathrm{kg}^{-1}$ of fresh matter, $188 \mathrm{~g}$ sugars kg-1 $, 5 \mathrm{~g}_{\text {fibre kg-1 }}, 3000 \mathrm{mg}$ potassium kg-1, 780 mg magnesium kg-1, $560 \mathrm{mg}^{-1}$ phosphorus $\mathrm{kg}^{-1}, 80 \mathrm{mg}$ calcium $\mathrm{kg}^{-1}$ and $13 \mathrm{mg}$ sodium $\mathrm{kg}^{-1}$. In addition, the sweet corn is a good source of vitamin $\mathrm{C}-66 \mathrm{mg} \mathrm{kg}^{-1}$, niacin - $19 \mathrm{mg} \mathrm{kg}^{-1}$, pantothenic acid - $7.3 \mathrm{mg} \mathrm{kg}^{-1}$ and vitamin E - $5.9 \mathrm{mg} \mathrm{kg}^{-1}$ (Uher et al., 2009).

The corn is also a plant with high production ability which is dependent on effective photosynthetic activity - C4 type of photosynthesis. Particular subspecies and varieties of corn are expressively different from the aspect of shape and colour of grain, spadix size, sugar content and endosperm composition, plant height, maturity period and way of their exploitation (Tracy, 1997).

The sweet corn is divided into three groups according to the sugar content and its storage ability. The first variety group consisted of varieties of normally sweet corn marked as su - it is derived from English term "sugar". After grain maturation, it is necessary to harvest corn spadix and sequentially process or consume by 24 hours. After this period, the content of sugars very quickly decreases and they are converted to starch (Salunkhe and Kadam, 1998). The second variety group is tagged as se (sugary enhanced). At these varieties, change of sugars to starch after harvest is slow. The corn spadix is possible to storage about 3 days after harvest in good taste quality (Singh et al., 2014). The third variety group is marked as sh-2 (super sweet, shrunken) and spadix has the highest sugar content and its storage ability after harvest is about 7 days in cold conditions. After that, the grain quality is decreased. The grain starts to shrivel because of water lack, despite of preserving sweet taste. This variety group is the most popular one by producers and consumers (Salunkhe and Kadam, 1998).

Sugars in sweet corn grain consist of fructose, glucose, saccharose and maltose and they are communally 
presented as total sugars. Taste or sugar content of sweet corn and spadix stability are parameters having important role for purchase by consumer (Singh, 2010). From this aspect, the most required varieties are characterized by sweet taste in milk grain maturity and keeping of high quality during longer periods. Due to its sweet taste, this delicious vegetable belongs to the most favourite foodstuffs in the world. It is consumed in fresh form or processed by conservation and freezing (Oktem et al., 2003). According to Dewanto et al. (2002), thermally processed sweet corn, despite of vitamin C loss, has conserved taste and increased antioxidant activity. Thus, it is a notable element for disease prevention and healthy life style.

The examined sweet corn varieties have their origins abroad. Thus, goal of this research work was to determine sugar content and selected variety characteristics of sweet corn in conditions of the Slovak Republic. The tested parameters are very important for sweet corn producers and consumers.

\section{Material and methods}

The field trial with sweet corn was established in the area of The Botanical garden of the Slovak University of Agriculture in Nitra in 2011 and 2012. We examined new varieties of sweet corn from aspect of basic variety parameters, important in the production practice, and changes of sugar content after harvest in the selected varieties. In this trial, we tested ten varieties of sweet corn (sh-2): SF $874 \mathrm{~F} 1$; RISING SUN F1; SF 583 F1; SF 681 F1; 1027 F1; SF 1073 F1; ASTRONAUT F1; GALAXY F1, SPACE SHIP F1 and MATADOR $F 1$. The evaluated varieties of sweet corn have origin in Spanish and Australian provenance and they are supplied to the Slovak market by company AGRITAR Komárno. The trial was founded by direct sowing into the planting space $0.60 \times$ $0.25 \mathrm{~m}$ on $27^{\text {th }}$ April in both experimental years. We sowed two rows at four repeatings of each variety. Each repeating concluded five plants. On the basis of soil analysis before trial establishment (Table 1), fertilization of corn was not needed.

The sweet corn plants were regularly irrigated and treated, according to signalisation of insects, mainly against butterfly invasion of European corn worm (Ostrinia nubilalis). The corn harvest was realised sequentially in dependency on grain maturing of particular varieties.

According to the valid descriptor of corn (Community Plant Variety Office, 2010), following characteristics of variety were evaluated: day number to relative maturity; day number from tassel anthesis to relative maturity; ear length; ear weight and grain proportion in ear.

The total sugar content was determined at five selected varieties of sweet corn (RISING SUN F1; 874 F1; SF 681 F1; GALAXY F1; MATADOR F1). The content of total sugars was determined spectrophotometrically by using of Somogy and Helson reagent in in two terms:

- immediately after harvest - within 24 hours,

- 4 days after harvest (spadixes were stock in refrigerator).

The obtained results were evaluated by analysis of variance (ANOVA). Tukey tests were performed on confidence level 95\%.

\section{Results and discussion}

\section{Variety characteristics}

Average values of variety parameters for the experimental period 2011-2012 are mentioned in Table 2. The vegetation period is the most important parameter from the aspect of

Table 1 Agrochemical soil characteristics before the establishment of the trial

\begin{tabular}{|c|c|c|c|c|c|c|c|c|}
\hline \multirow[t]{2}{*}{ Year } & \multirow[t]{2}{*}{$\mathrm{pH} / \mathrm{KCl}$} & \multicolumn{6}{|c|}{ Content of nutrients in $\mathrm{mg} \mathrm{kg}^{-1}$ of soil } & \multirow[t]{2}{*}{$\%$ of humus } \\
\hline & & $\mathbf{N}_{\min }$ & $\mathbf{P}$ & $\mathbf{K}$ & $\mathbf{S}$ & $\mathrm{Ca}$ & Mg & \\
\hline 2011 & 6.96 & 46.8 & 130 & 575 & 32.5 & 7300 & 662.5 & 3.79 \\
\hline 2012 & 6.67 & 20.4 & 128 & 530 & 37.5 & 6370 & 654 & 3.76 \\
\hline
\end{tabular}

Table 2 Average value of sweet corn variety characteristics for period 2011-2012

\begin{tabular}{|c|c|c|c|c|c|}
\hline Variety & Days to RM & Days from TA to RM & Ear length in cm & Ear weight in $\mathbf{g}$ & Grain proportion in \% \\
\hline SF 874 F1 & 88 & 22.5 & 18.5 & 183.0 & 99.0 \\
\hline RISING SUN F1 & 82.5 & 21.5 & 21.0 & 269.5 & 93.5 \\
\hline SF 1073 F1 & 89.5 & 24.5 & 19.5 & 262.0 & 99.0 \\
\hline SF 583 F1 & 90.5 & 25.0 & 19.5 & 247.0 & 92.5 \\
\hline SF 681 F1 & 94.5 & 26.0 & 20.0 & 220.0 & 99.0 \\
\hline $1027 \mathrm{~F} 1$ & 98.0 & 28.5 & 21.0 & 236.5 & 92.5 \\
\hline ASTRONAUT F1 & 97.0 & 26.5 & 21.0 & 262.5 & 92.5 \\
\hline GALAXY F1 & 101.5 & 27.0 & 22.0 & 260.5 & 99.0 \\
\hline SPACE SHIP F1 & 102.5 & 28.0 & 20.0 & 243.0 & 92.5 \\
\hline MATADOR F1 & 106.5 & 31.0 & 21.5 & 253.5 & 92.5 \\
\hline
\end{tabular}


sweet corn producers. According to earliness, we classified the evaluated varieties to the following groups: very early or early (RISING SUN F1; SF 874 F1; SF 1073 F1; SF 583 F1); middle-late (SF $681 \mathrm{~F} 1 ; 1027 \mathrm{~F} 1$; ASTRONAUT F1); late (GALAXY F1; SPACE SHIP F1) and very late (MATADOR F1). Other important parameters influencing the variety selection for cultivation are day number from tassel anthesis to harvest, grain proportion, length and weight of ear.

The average period from anthesis to harvest ranged from 21.5 to 31 days and its lowest value was determined at the variety RISING SUN F1. The highest average proportion of grain was found at the varieties SF 874 F1, SF 1073 F1, SF $681 \mathrm{~F} 1$ and GALAXY F1. The highest value of ear length was found at the variety GALAXY F1 $(22.0 \mathrm{~cm})$. The highest ear weight was evaluated at the variety RISING SUN F1 (269.5 g). The grain proportion, weight and length of ears belong to basic parameters influencing the total yield of cultivated sweet corn varieties. This fact was presented in the research works of several authors which stated significant impact of variety to the yield quantity of sweet corn (Hassan, 2000; Shafi et al., 2012; Eskandarnejad et al., 2013).

\section{Sugar content}

In our experiment, the total sugar content was analysed within 24 hours after harvest and on the $4^{\text {th }}$ day after harvest at 5 selected varieties of sweet corn (Table 3). Immediately after harvest, the content of total sugars ranged from

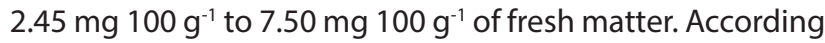
to the total sugar content, all evaluated varieties were classified to the group of super-sweet corn (sh-2).

The highest sugar content was detected at the variety 874 F1. On the contrary, its lowest value was determined at the variety MATADOR F1. At both mentioned varieties of sweet corn, we found statistically significant difference of total sugar content compared to other evaluated varieties of sweet corn. From these results, it is possible to state that variety is factor expressively determining the sugar content in sweet corn or plants generally. This fact was previously proved by several authors in experiments with various crops - sweet corn (Russo and Fish, 2012), sweet cane, sugar beet (Singh, 2010) or sweet sorghum (Zhao et al., 2009).

According to the gained experimental results, storage tended to the lower content of total sugars in sweet corn. At 4th day after harvest, the total sugar content was decreased at all examined varieties in comparison with its value within 24 hours after harvest. The average sugar content

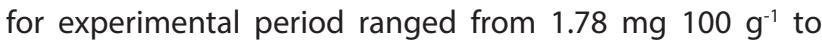
$6.33 \mathrm{mg} 100 \mathrm{~g}^{-1}$ of fresh matter. The highest content of total sugars was determined at the variety $874 \mathrm{~F} 1$. The lowest sugar content was detected at the variety MATADOR F1. At this variety, we also found the most expressive decrease of the total sugar content compared to the sugar content immediately after harvest, concretely about $27.35 \%$.

The analysis of variance of the gained results showed statistically significant impact of storage to the total sugar content in sweet corn (Table 4). Despite the sugar content decrease, corn spadixes were still sweet and suitable for consumption without visible symptoms of grain shrinkage. Barkoci (2004) presented that sweet corn lost 50\% of sugar content during 24 hours at temperature $20{ }^{\circ} \mathrm{C}$. This fact can be eliminated by storing in cool atmosphere. Our results confirmed that storage of corn spadixes at lower temperature in refrigerator resulted in less expressive decrease of the total sugar content. After the storage period of 4 days, we found statistically significant decrease of its average value about $20.4 \%$ (Table 5).

\section{Conclusion}

The experiment was realised in conditions of the southern Slovakia, specifically in the area of The Botanical Garden of the Slovak University of Agriculture in Nitra in 2011 and 2012. In the field trial with sweet corn, we evaluated a new assortment of sweet corn varieties from the aspect of basic variety data important within production practice. In addition, we examined the total sugar content and its change after harvest in selected varieties of sweet corn.

According to earliness, we classified evaluated varieties to the following groups: very early or early (RISING SUN

Table 3 Total sugar content in sweet corn grain $\left(\mathrm{mg}^{\left.100 \mathrm{~g}^{-1}\right)}\right.$ in 2011

\begin{tabular}{|l|c|c|c|c|c|c|}
\hline \multirow{2}{*}{ Variety } & \multicolumn{3}{|c|}{ 24 hours after harvest } & \multicolumn{3}{c|}{ 4 $^{\text {th }}$ day after harvest } \\
\cline { 2 - 7 } & $\mathbf{2 0 1 1}$ & $\mathbf{2 0 1 2}$ & average & $\mathbf{2 0 1 1}$ & $\mathbf{2 0 1 2}$ & average \\
\hline 874 F1 & 8.70 & 6.30 & $7.50 \mathrm{a}$ & 7.00 & 5.65 & $6.33 \mathrm{a}$ \\
\hline RISING SUN F1 & 5.65 & 3.80 & $4.73 \mathrm{~b}$ & 4.65 & 3.40 & $4.03 \mathrm{~b}$ \\
\hline SF 681 F1 & 6.30 & 3.10 & $4.70 \mathrm{~b}$ & 4.40 & 2.70 & $3.55 \mathrm{~b}$ \\
\hline GALAXY F1 & 4.58 & 4.40 & $4.49 \mathrm{~b}$ & 4.00 & 3.05 & $3.53 \mathrm{~b}$ \\
\hline MATADOR F1 & 2.30 & 3.60 & $2.45 \mathrm{c}$ & 1.50 & 1.95 & $1.78 \mathrm{c}$ \\
\hline
\end{tabular}

Different letters between rows $(a, b, c)$ show statistically significant differences at the level $a=0.05$

Table 4 The effect of storage to the sugar content in sweet corn (LSD, 95\%)

\begin{tabular}{|l|c|c|}
\hline Variant & LS Mean* & Homogeneous groups \\
\hline $\mathbf{2 4}$ hours after harvest & 4.80 & $\mathrm{a}$ \\
\hline $\mathbf{4}^{\text {th }}$ day after harvest & 3.82 & $\mathrm{~b}$ \\
\hline
\end{tabular}

* average value of total sugar content counted from examined varieties of sweet corn. Different letters between rows (a, b) show statistically significant differences at the level $\alpha=0.05$ 
F1; SF 874 F1; SF 1073 F1; SF 583 F1); middle-late (SF 681 F1; 1027 F1; ASTRONAUT F1); late (GALAXY F1; SPACE SHIP F1) and very late (MATADOR F1). The average period from anthesis to harvest ranged from 21.5 to 31 days and its lowest value was determined at the variety RISING SUN F1. The highest average proportion of grain was found at the varieties SF 874 F1, SF 1073 F1, SF 681 F1 and GALAXY F1.

According to the total sugar content, all evaluated varieties were classified to the group of super-sweet corn (sh-2). Immediately after harvest, the content of total

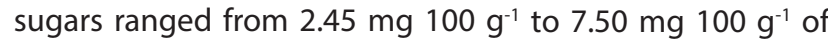
fresh matter. The highest sugar content was detected at the variety $874 \mathrm{~F} 1$. On the contrary, its lowest value was determined at the variety MATADOR F1. Sequential storage tended to the statistically significant decrease of the total sugar content in sweet corn. At $4^{\text {th }}$ day after harvest, the total sugar content was lower at all examined varieties in comparison with its value within 24 hours after harvest. The average sugar content for the experimental period ranged from $1.78 \mathrm{mg} / 100 \mathrm{~g}$ to $6.33 \mathrm{mg} 100^{-1} \mathrm{~g}$ of fresh matter.

\section{References}

ABUZAR, M. R. - SADOZAI, G. U. - BALOCH, M. S. - BALOCH, A A. - SHAH, I. H. - JAVAID, T. - HUSSAIN, N. 2011. Effect of plant population densities on yield of Maize. In Journal of Animal and Plant Sciences, vol. 21, 2011, no. 4, p. 692-965. ISSN 1018-7081.

BARKOCI, Š. 2004. Kukurica cukrová, pukancová ako lahôdková zelenina. Pôdohospodársky poradenský systém. [online]. Available at: http://old.agroporadenstvo.sk/rv/krmoviny/kukurica.htm?start [Accessed: 2014, July 26].

COMMUNITYPLANTVARIETYOFFICE. 2010. Protocol for distinctness, uniformity and stability tests. Zea mays L. Maize. Angers: CPVO, $51 \mathrm{p}$. DEWANTO, V. - WU, X. - LIU, R. H. 2002. Processed Sweet Corn Has Higher Antioxidant Activity. In Journal of Agricultural and Food Chemistry, vol. 50, 2002, no. 17, p. 4959-4964. ISSN 0021-8561.

ESKANDARNEJAD, S. - KHORASANI, S. K. - BAKHTIARI, S. HEIDARIAN, A. R. 2013. Effect of row spacing and plant density on yield and yield components of Sweet corn (Zea mays L. Saccharata) varieties. In Advanced Crop Science, vol. 3, 2013, no. 1, p. 81-88. ISSN 2329-8863.

HASSAN, A. A. 2000. Effect of plant population density on yield and yield components of 8 Egyptian maize hybrids. In Bulletin of the
Faculty of Science of Cairo University, vol. 51, 2000, no. 1, p. 1-16. ISSN 0526-8613.

MERAVÁ, E. 2012. Vegetable : Situational and perspective review on the date 31. 12.2011. Bratislava : Research Institute of Agricultural and Food Economics, 55 p. ISSN 1338-8010.

MORADI DEZFULI, P. - SHARIF-ZADEH, F. - JANMOHAMMADI, $M$. 2008. Influence of priming techniques on seed germination behavior of maize inbred lines (Zea mays L.). In American Journal of Agricultural and Biological Science, vol. 3, 2008, no. 3, p. 22-25. ISSN 1990-6145.

OKTEM, A. - SIMSEK, M. - OKTEM, A. 2003. Deficit irrigation effects on sweet corn (Zea mays convar. saccharata Sturt) with drip irrigation system in a semi-arid region. I. Water yield relationship. In Agricultural Water Management, vol. 61, 2003, no. 1, p. 63-74. ISSN 0378-3774.

RUSSO, V. M. - FISH, W. W. 2012. Biomass, extracted liquid yields, sugar content or seed yields of biofuel feedstocks as affected by fertilizer. In Industrial Crops and Products, vol. 36, 2012, no. 1, p. 555-559. ISSN 0926-6690.

SALUNKHE, D. K. - KADAM, S.S. 1998. Sweet corn. Handbook of vegetable science and technology, production, composition, storage and processing. New York: Marcel Dekker, 742 p. ISBN 0-8247-0105-4.

SHAFI, M. - BAKHT, J. - ALI, S. - KHAN, H. - KHAN, M. A. - SHARIF, M. 2012. Effect of planting density on phenology, growth and yield of maize (Zea mays L.). In Pakistan Journal of Botany, vol. 44, 2012, no. 2, p. 691-696. ISSN 0556-3321.

SINGH, B. 2010. Industrial Crops and Uses. Wallingford: CABI, 528 p. ISBN 978-1-84593-616-7.

SINGH, I. - LANGYAN, S. - YADAVA, P. 2014. Sweet Corn and CornBased Sweeteners. In Sugar Technology, vol. 16, 2014, no. 2, p. 144 149. ISSN 0972-1525.

TRACY, W. F. 1997. History, genetics, and breeding of supersweet (shrunken2) sweet corn. In Plant Breeding Reviews, vol. 14, 1997, p. 189-236. ISSN 0730-2207.

UHER, A. - KÓŇA, J. - VALŠíKOVÁ, M. - ANDREJIOVÁ, A. 2009. Zeleninárstvo: polné pestovanie. Nitra: SPU, 212 s. ISBN 978-80-552-0199-3.

ZHAO, Y. L. - DOLAT, A. - STEINBERGER, Y. - WANG, X. - OSMAN, A. $\mathrm{XIE}, \mathrm{G}$. H. 2009. Biomass yield and changes in chemical composition of sweet sorghum cultivars grown for biofuel. In Field Crops Research, vol. 111, 2009, no. 1-2, p. 55-64. ISSN 0378-4290. 